УДК 94 (497.5) «1990-1999»

DOI: https://doi.org/10.33782/eminak2019.3(27).325

\title{
ПЕРЕХІДНІ ПОЛІЦІЙНІ СИЛИ ПІД ЧАС РЕІНТЕГРАЦІЇ ХОРВАТСЬКОГО ПОДУНАВ'Я: УРОКИ ДЛЯ УКРАЇНИ
}

\author{
Микола Нагірний \\ Вищий комунальний навчальний заклад «Володимир-Волинський педагогічний ко- \\ ледж імені А.Ю. Кримського» (Володимир-Волинський, Україна) \\ e-mail: mykola76@hotmail.com; mykola-docent@ukr.net \\ ORCID: http://orcid.org/0000-0002-9319-8540
}

У статті розглянуто процес створення та діяльність національно змішаних правоохоронних сил на території хорватського Подунав'я під час реінтеграції цього регіону до складу Хорватії у другій половині 1990-х років. Проаналізовано труднощі у діяльності Перехідної поліції, вимоги сторін конфлікту під час формування «нової поліції». Висловлено припущення, чи можна хорватський досвід зі створення тимчасових багатонаціональних поліційних сил використати у сучасних українських реаліях.

Ключові слова: УНТАЕС, реінтеграція, Перехідні політичні сили, Подунав'я

Сучасні геополітичні виклики, з якими стикається Україна з 2014 р., спонукають шукати їхнього вирішення на прикладах нещодавньої історії близьких нам (територіально, історично та ментально) країн. Щодо досі невирішеного питання т.зв. ОРДЛО - а це фактично одна з ключових проблем сучасної України - знаходимо подібності у хорватському досвіді.

Вихід Хорватії зі складу Югославії на початку 1990-х рр. не проходив безболісно. Проблема стосунків хорватів і сербів займала важливе місце у житті республіки. Останні, складаючи $12 \%$ населення Хорватії, займали ключові пости у поліції й адміністрації республіки.

Майже всі серби сприйняли демократичні зміни у Хорватії на межі 1980-90-х років як перемогу радикальних правих сил 1 . Більшість сербів не могли уявити своє життя поза Югославією.

Непопулярні кроки хорватського уряду (масові звільнення з адміністративних посад сербів) посилювали сепаратистські настрої найбільшої національної меншини Хорватії, чому сприяла і пропаганда з Белграда ідей «Великої Сербії». Хорватські серби взяли курс на автономію та максимальне дистанціювання від Загреба, а з серпня 1990 р. почали переймати контроль над територіями з сербською більшістю (це був початок так званої барикадної революції) ${ }^{2}$.

Важливість сербського питання хорватський уряд спочатку недооцінював, а вимоги культурної автономії для сербів відкидав³.

Із переходом сербських військ через Дунай (хорватсько-сербський міжреспубліканський кордон) у липні 1991 р. розпочалася повномасштабна війна, яка посилила

\footnotetext{
${ }^{1}$ Bilandžić D. Hrvatska moderna povijest. Zagreb: Golden Marketing, 1999. S. 777.

2 Нагірний М. Становлення та розвиток Республіки Хорватія: державно-політичний аспект. Нововолинськ: Мінотавр, 2007. С. 37.

${ }^{3}$ Lukić R. Greater Serbia: A New Reality in the Balkans // Nationalities Papers (New York). 1994. Spring. Vol. 22. No. 1. P. 52-53.
} 
міжнаціональний антагонізм, спричинила практику етнічних чисток і виникнення величезної кількості біженців і вигнанців. Під захистом регулярних сил сербської армії хорватські серби на кінець 1991 р. повністю відокремилися від Хорватії, узявши під контроль чверть їі території. Повернення втрачених земель стало нагальною та першочерговою потребою хорватської влади.

Задля повернення відокремлених сербських областей під юрисдикцію Загреба на початку 1992 р. у Хорватію було введено миротворчий контингент ООН. Однак його діяльність виявилася неефективною. Незадоволена миротворцями Хорватія, за сприяння США, відновила воєнні дії та повернула більшу частину втрачених територій. У цій ситуації ООН спромоглася лише вирішити мирним шляхом проблему Східної Славонії та суміжних земель (т. зв. хорватське Подунав'я), що залишалися під контролем сербських сепаратистів.

3 жовтня 1995 р. у східнославонському місті Ердут хорватський уряд і місцеве сербське керівництво підписали договір з 11-ти пунктів, спрямованих на урегулювання суперечливих питань. Іншим кроком у напрямку мирного врегулювання був договір, підписаний 12 листопада Загребом і місцевими сербами, за участі представників ООН і США, під назвою «Основна угода про поступову мирну реінтеграцію Східної Славонії, Барані та Західного Срієму до конституційного простору Хорватії».

Договір пропонував дворічний «перехідний період» для реінтеграції ${ }^{4}$ Для цього передбачався 12-місячний термін, який міг бути продовжений ще на рік за бажанням однієї зі сторін. На цей час Рада Безпеки ООН мала встановити Перехідну адміністрацію як орган управління у Східній Славонії. Перехідна адміністрація повинна була сприяти поверненню біженців і вигнанців, які отримали право на повернення майна. Територія Східної Славонії мала бути демілітаризована. Перехідна адміністрація повинна була організувати місцеві вибори та допомогти сербській спільноті вибрати Віче общин (виборний орган влади регіону - Aвm.)5.

Правоохоронна система Подунав'я теж мала бути реінтегрована. Це було зроблено шляхом створення перехідних і змішаних хорватсько-сербських поліцейських сил. Одним із елементів поступової реінтеграції регіону у державно-правове поле Хорватії стала організація роботи Перехідних поліційних сил (ППС, або ТРF Transitional Police Forces).

Саме особливості організації правоохоронних органів та їх роботи на території, яка підлягала реінтеграції, і присвячена дана стаття. Її актуальність посилюється подібністю процесів у Хорватії другої половини 1990-х років і сучасних подій на сході України). Можливість повернення частини Донбасу до правового поля України безумовно поставить питання організації сил правопорядку на звільнених територіях. Й у цьому контексті вивчення досвіду Хорватії буде дуже корисним.

Сербсько-хорватська війна - найпопулярніша тема сучасної хорватської історичної науки. А от проблемам реінтеграції присвячено значно меншу кількість розвідок. Зокрема, питання діяльності Перехідної поліції у своїх дослідженнях підіймали хор-

\footnotetext{
${ }^{4}$ Klemenncic M., Schofield C. Croatia's territorial consolidation and prospects for the future // GeoJournal (Dordrecht; Boston; London). 1996. April. Vol. 38. No. 4. P. 397.

5 Tatalović S. Manijinski narodi i manjine. Zagreb: IP Prosvjeta: SKD Prosvjeta, 1997. S. 284-285.
} 
вати Н. Барич6 та А. Холевац Тукович7, а також західні представники міжнародних структур у регіоні - Ж.-П. Клейн ${ }^{8}$ і К. Колейро ${ }^{9}$. Джерельним матеріалом слугують тогочасні публікації у періодичних виданнях Хорватії та Сербії - Vukovarske novine, Borba, Glas Slavonije тощо.

Метою нашої статті є показати ті сторони діяльності ППС, які можна використати в якості прикладів для ефективної реінтеграції тимчасово окупованих територій до складу України. Завданнями даної роботи $є$ висвітлення причин створення Перехідних сил поліції, розгляд особливостей їхньої діяльності у регіоні, аналіз взаємодії правоохоронців у трикутнику «хорвати - серби - світова спільнота».

15 січня 1996 р. Рада Безпеки ООН прийняла резолюцію № 1037 про створення Перехідної адміністрації ООН у Східній Славонії під назвою УНТАЕС (англ. UNTAES United Nations Temporary Administration in East Slavonia), у розпорядження якої було надано 5 тис. миротворців $0 \mathrm{OH}^{10}$.

Окрім міжнародного контингенту, відповідно до положення згаданої Резолюції, під адміністративним наглядом ООН на території хорватського Подунав'я мала бути створена багатонаціональна поліція. Перехідна адміністрація отримала мандат на створення тимчасових поліційних сил, повноваження визначати їх склад і розмір, розробити навчальну програму для працівників і контролювати їі виконання. УНТАЕС також брала на себе зобов'язання контролювати кримінальні провадження у регіоні та здійснювати там моніторинг пенітенціарної системи, інформуючи про усе це Генерального секретаря ООН. Контроль за правопорядком у регіоні покладався на Перехідні поліцейські сили.

Робота ППС тривала паралельно з іншими процесами, які були складовими елементами реінтеграції: демілітаризація регіону, адміністративна реінтеграція, соціальна реінтеграція, проведення місцевих виборів, відновлення економіки11.

Запровадження Перехідної поліції залежало від першого кроку з реінтеграції Подунав'я - демілітаризації. Вона передбачала роззброєння всіх паравійськових сил регіону. План демілітаризації миротворці розробляли спільно з Генеральним штабом югославської армії та командуванням 11-го корпусу ЮНА. Сербське військове керівництво намагалося уникнути роззброєння своїх військ, однак керівництво УНТАЕС відкинуло сербські пропозиції.

20 червня 1996 р. демілітаризацію Подунав'я було завершено. Підрозділи югославської армії було виведено до Сербії, місцеві збройні формування розпущено. Перехідна адміністрація взяла під свій контроль казарми, аеродром і нафтові родовища12.

\footnotetext{
${ }^{6}$ Barić N. Srpska oblast Istočna Slavonija, Baranja i Zapadni Srijem - od «Oluje» do dovršetka mirne reintegracije hrvatskog Podunavlja (prvi dio) // Scrinia Slavonica: Godišnjak Podružnice za povijest Slavonije, Srijema i Baranje Hrvatskog instituta za povijest. 2011. № 11 (1). S. 409-415; Barić N. Srpska oblast Istočna Slavonija, Baranja i Zapadni Srijem - od «Oluje» do dovršetka mirne reintegracije hrvatskog Podunavlja (drugi dio) // Scrinia Slavonica: Godišnjak Podružnice za povijest Slavonije, Srijema i Baranje Hrvatskog instituta za povijest. 2012. № 12 (1). S. 327-328.

${ }^{7}$ Holjevac Tuković A. Proces mirne reintegraciji Hrvatskog Podunavlja. Zagreb: Despot infinitus [etc.], 2015. 8 Klein J.P. UNTAES - sažeto izvješće misije // Mirna reintegracija Hrvatskoga Podunavlja - znanstveni, empirijski i iskustveni uvidi [ured. D. Živić, S. Cvikić]. Zagreb-Vukovar: Institut društvenih znanosti Ivo Pilar, 2010. S. 17-22.

${ }^{9}$ Coleiro C. Bringin Peace to the Land of Scorpions and Jumping Snakes: Legacy of the United Nations in Eastern Slavonia and Transitional Missions, canadian Peacekeeping Press, 2002.

10 Pavličević D. Povijest Hrvatske. Zagreb: Naklada P.I.P. Pavičić, 2000. S. 553.

11 Klein J.P. UNTAES - sažeto izvješće misije... S. 22.

12 Barić N. Op. cit. (prvi dio). S. 409-415.
} 
Ще до завершення демілітаризації поступово почали формуватися ППС. Очільник УНТАЕС Жак-Поль Клейн запропонував сторонам направити своїх правоохоронців пройти спільні навчання у Відні та Будапешті, після чого вони повинні були повернутися до Подунав'я та взяти на себе обов'язки поліції13. У квітні 1996 р. перша така група (150 сербських міліціонерів і 150 хорватських поліціянтів) відправилася до Будапешту, де почалася підготовка мультинаціональних поліційних сил. Це була перша (з часів вибуху сербсько-хорватської війни у 1991 р.) спроба реалізувати програму, в якій брали участь разом хорвати та серби. Попри поширений скепсис щодо ефективності такого кроку, навчання у Будапешті підготувало їх до спільної роботи в етнічно розділених районах Подунав'я14. За задумом Ж.-П. Клейна, загалом у Будапешті повинні були пройти підготовку 440 хорватських і сербських поліціянтів 15.

Однак сербське керівництво регіону прагнуло затягнути процес реінтеграції загалом і створення ППС, зокрема. Так, самопроголошений сербський лідер Подунав'я Горан Хаджич заявляв, що відправка сербських поліцейських на навчання до Угорщини була просто символічним актом, а «хорватська міліція не хоче приїжджати у цей регіон із такою структурою населення, навіть ціною власного звільнення». Висновком можна вважати його заяву: «Якщо ми підемо, то втратимо все»16. Тобто, керівники сепаратистів розраховували, якщо у регіоні залишиться якомога більше сербів, то хорвати будуть менш схильні повернутися сюди. Такою політикою вони прагнули утримати якомога більше сербів у Подунав'ї (як місцевих, так і прибулих після 1991 р.), а також отримати чисельну перевагу задля майбутнього розширення прав місцевого самоврядування й у кінцевому підсумку досягнення територіальної автономії 17.

Сербська сторона по-своєму трактувала положення Резолюції РБ ООН про багатонаціональну поліцію. У лютому 1996 р. на громадському форумі в Ілоку, присвяченому статусу та проблемам сербів у регіоні, тодішній лідер сербської переговорної групи Мілан Міланович заявив, що у змішаних поліцейських патрулях не буде хорватських поліцейських, а тільки представники УНТАЕС і сербська поліція. Він також додав, що «сербські поліцейські на одному рукаві будуть носити знак «УНТАЕС», а на іншому - традиційний знак сербської поліції»18.

Уніформа була однією з перших проблем Перехідної поліції, оскільки для хорватської влади було неприйнятним, щоб серби носили однострої «країнської міліції»19 під час перехідного періоду, і вона наполягала, аби ті носили нейтральну уніформу. Зокрема, в якості основного було запропоновано чорний колір. Сербська сторона відмовилася від пропозиції з поясненням, що така форма нагадує про фашизм (у часи Другої світової війни хорватські усташі носили чорні сорочки) ${ }^{20}$.

7 березня 1997 р. на зустрічі з представниками МВС Хорватії та представниками УНТАЕС серби взагалі вимагали, аби нова уніформа не була схожою з офіційною хорватською формою. Те ж саме стосувалося і транспортних засобів, які не повинні були

\footnotetext{
${ }^{13}$ Barić N. Op. cit. (drugi dio). S. 327-328.

${ }^{14}$ Coleiro C. Op. cit. P. 99.

15 Barić N. Op. cit. (drugi dio). S. 328.

16 Poštovaće se volja naroda // Borba (Beograd). 1996. 11-12.05. S. 6.

17 Koga 'prelaze' prijelazni policajci // Glas Slavonije (Osijek). 1997. 28.01. S.12.

18 'Stop' za hrvatsku policiju // Vukovarske novine (Vukovar). 1996. 17.02. S. 1.

19 Республіка Сербська Країна - самопроголошене державне утворення на території Хорватії у 1990-х роках. - Авт.

${ }^{20}$ Holjevac Tuković A. Op. cit. S. 105.
} 
нагадувати поліційні машини хорватського МВС. Ідентифікаційні картки поліціянтів також мали бути без національних або регіональних знаків.

У результаті тристоронніх перемовин було вирішено, що уніформа поліціянтів буде темно-синьою і без позначок (за винятком напису «Поліція» англійською мовою), і що їхні ідентифікаційні картки друкуватимуть тільки із написом «Тимчасова адміністрація ООН». Єдиною ознакою службових машин Перехідної поліції мало бути маркування «ППС»21.

Своєю чергою, хорватська сторона подала клопотання вилучити 197 осіб зі списку працівників сербської міліції, яка мала бути складовим підрозділом Перехідної поліції. Заступник прем'єр-міністра Хорватії Івіца Костович заявив, що спочатку застереження були щодо 600 осіб сербської національності, оскільки вони брали участь у збройному повстанні проти Республіки Хорватія. Однак близько 400 з них згодом підпали під дію Закону про амністію. На решту претендентів дія цього закону не поширювалася, оскільки їх підозрювали у тяжких і військових злочинах. Деррек Бутбі (Derrek Boothby), заступник глави УНТАЕС, прийняв це обгрунтування, але попросив, щоб перелік було повторно переглянуто у бік зменшення «з урахуванням тяжкості злочину»22.

Перехідні поліційні сили почали працювати у регіоні 1 липня 1996 р. на контрольно-пропускному пункті між Бршадіном і Нуштрою23. Очільником ППС було призначено серба Петара Джукіча, його заступником - хорвата Йосипа Мілічевича. Передбачалося, що Перехідні поліцейські сили комплектуватимуться професіоналами, які виконуватимуть свою місію, забезпечуючи мир і безпеку для кожного громадянина 24 .

На той час навчання у столиці Угорщини завершило 1600 поліціянтів, з яких 1200 було сербами і 400 - хорватами 25 . Хоча, за даними заступника Перехідної поліції Й. Мілічевіча, у складі ППС було 1300 сербів і тільки 195 хорватів 26.

Територію хорватського Подунав'я розділили на сектори «Північ» (ОсієцькоБаранська поліційна адміністрація, з осідком у містах Белі Манастір та Осієк) і «Південь» (Вуковарсько-сріємська поліційна адміністрація зі штаб-квартирою у Вуковарі та Вінковцях). Згідно з Меморандумом про взаєморозуміння, підписаним між МВС Хорватії й УНТАЕС, у секторі «Північ» командувати поліцією мав серб за національністю, а у секторі «Південь» - хорват. Поліційні патрулі мали складатися з одного хорвата, одного серба й одного представника від УНТАЕС. Також до складу Перехідної поліції увійшло 400 представників Перехідної адміністрації ООН 27.

Ж.-П. Клейн заявив, що на лінії розмежування між хорватською та сербською сторонами і на частині автомагістралі Загреб-Белград поліція працюватиме у співвідношенні «половина хорватів - половина сербів» (по два з кожного боку), але у межах Східної Славонії буде діяти винятково «сербська міліція» ${ }^{28}$. Тому УНТАЕС у м. Ердут також проводила додаткове навчання т.зв. «обласної міліції», яка налічувала 600 сербських міліціонерів.

\footnotetext{
${ }^{21}$ Barić N. Op. cit. (drugi dio). S. 327-328.

22 Holjevac Tuković A. Op. cit. S. 106.

${ }^{23}$ Barić N. Op. cit. (drugi dio). S. 327-328.

24 Zajedničke policijske patrole // Vukovarske novine. 1996. 12.07. S. 1.

25 Klein J.P. UNTAES - sažeto izvješće misije... S. 23.

${ }^{26}$ Gdje su hrvatski policajci? // Večernji list (Zagreb). 1996. 29.10. S. 6.

27 Zajedničke policijske patrole // Vukovarske novine. 1996. 12.7. S. 1; Holjevac Tuković A. Op. cit. S. 106.

${ }^{28}$ Holjevac Tuković A. Op. cit. S. 107.
} 
Одразу ж гостро постало питання національного співвідношення поліціянтів, оскільки переміщені особи хорватської національності не хотіли повертатися у Подунав'я, допоки співвідношення сил у ППС було виразно на користь сербів. Тому Й. Мілічевіч пропонував поступово (кожні 15 днів) збільшувати кількість хорватів у структурі ППС на 530 осіб, беручи до уваги тогочасний національний склад регіоHy 29 .

На межі 1996-97 рр. на території Подунав'я трапилася низка неприємних для Хорватії інцидентів: напади на журналістів у Вуковарі, на автобус співробітників МВС Хорватії та місцеві банки; вбивство хорватки у м. Ілок, коли місцева влада через правоохоронців сприяла злочинцям, аби ті втекли до Югославії. У всіх випадках правоохоронні органи показали свою неефективність. У зв'язку з цими подіями та нестабільністю у хорватському Подунав'ї міністр внутрішніх справ Хорватії Іван Пеніч направив скарги до Ж.-П. Клейна на роботу Перехідної поліції, підкреслюючи необхідність зміни національної структури поліції, в якій більшість було сербами, і наполягаючи, що ППС повинна адаптувати роботу та структуру до норм МВС Хорватії. Однак УНТАЕС оцінювала вищезгадані події як поодинокі інциден$\mathrm{TИ}^{30}$.

Хорватський уряд пропонував сербським працівникам ППС отримати громадянство Хорватії, після чого вони підписували трудові договори та ставали повноправними хорватськими поліціянтами. Це викликало незадоволення сербської сторони. Сербська преса Подунав'я повідомляла, на сербів - співробітників ППС тиснуть, аби ті погодилися взяти хорватські документи й отримувати зарплату в кунах (національна валюта Хорватії - Aвm.) ${ }^{31}$. Це питання також хвилювало й УНТАЕС. Зокрема, Ж.П. Клейн наводив дані, що 100 працівників поліції сербської національності готові приймати документи Хорватії, але 800 поліціянтів не хочуть цього робити ${ }^{32}$.

Інші побоювання сербів стосувалися змін у складі ППС, оскільки туди щомісяця входили по 50 поліцейських (як правило хорватів). Станом на 1 червня 1997 р. Перехідні поліцейські сили складалися з 2000 чоловік, з яких 1150 - серби, а решта - хорвати та члени інших національностей 33 .

Коли у квітні 1997 р. хорватська влада призначила пенсію сербському начальнику ППС П. Джукичу, він відмовився, пояснивши, що залишиться у поліції, доки усім сербським поліціянтам не гарантують забезпечення усіх їхніх прав. Очевидно, йшлося про задум хорватського уряду запровадити для членів ППС випробувальний період для прийому на роботу тривалістю протягом трьох місяців, з обов'язковим фаховим іспитом до 1 червня 1998 р. П. Джукич заявив, що кількість членів ППС по суті зменшилася на третину, і що більшість поліціянтів не мають чіткого майбутнього ${ }^{34}$.

Процес реінтеграції територій під контролем УНТАЕС проходив не завжди спокійно. Мала місце низка інцидентів на міжнаціональному грунті. Зокрема, серби блокували відвідини хорватськими біженцями своїх домівок та костелів, намагалися зірвати регіональні вибори навесні 1997 р.; хорвати ж мстилися сербам, якщо ті

\footnotetext{
${ }^{29}$ Gdje su hrvatski policajci?... S. 6.

${ }^{30}$ Koga 'prelaze' prijelazni policajci... S. 12; Holjevac Tuković A. Op. cit. S. 107.

31 Menja li se sastav PPS? // Vukovarske novine. 10.1.1997. S. 1.

32 Holjevac Tuković A. Op. cit. S. 108.

${ }^{33}$ Barić N. Op. cit. (drugi dio). S. 329.

34 Petar Đukić odbio penzionisanje // Vukovarske novine. 1997. 26.4. S. 3.
} 
опинялися на підконтрольних офіційному Загребу територіях 35.

ППС разом із представниками УНТАЕС мали кілька варіантів залагодження конфліктів і стабілізації ситуації: переговори зі сторонами конфлікту; використання сльозоточивого газу та фізичної сили; залякування населення, що у випадку ескалації напруженості може бути гірше. Наприклад, після відкриття шосе Осієк-Вінковці, яке проходило по території під контролем УНТАЕС, сербське населення з Ернестінова на початку 1997 р. скаржилося на агресивну поведінку прибулих хорватів. Селяни вимагали посилити контроль за в'їздом на територію під тимчасовим управлінням ООН, а також збільшити чисельність Перехідної поліції у регіоні. У відповідь, начальник поліційного посту ППС у с. Маркушіца порадив незадоволеному населенню не реагувати на хорватські провокації, тому що це могло дати привід хорватській владі вдатися до інтервенції зі своєю поліцією й армією 36.

3 продовженням реінтеграції частка хорватів у Перехідних поліцейських силах зросла. Із середини 1997 р. розпочалася реструктуризація цього органу та поступове переведення його співробітників до складу хорватського $\mathrm{MBC}^{37}$.

Ж.-П. Клейн і хорватський міністр внутрішніх справ Іван Пеніч узгодили реформування Перехідної поліції з 1 липня 1997 р. Відбулася ротація у керівництві ППС: серба П. Джукича замінив хорват Іван Бабіч. Припинила діяти тодішня система подвійного управління. Перехідна поліція надалі залишалася під керівництвом Ж.П. Клейна, але відбувався поступовий процес ії інтеграції до складу МВС Хорватії. Усім сербським поліціянтам було запропоновано роботу в хорватському Міністерстві внутрішніх справ, і вони повинні були визначитися до 15 липня 1997 р. 3 реформуванням поліції були внесені інші необхідні зміни, що стосувалися зміни форми та відзнак ${ }^{38}$.

Станом на середину 1997 р. 750 правоохоронців сербської національності підписали нові трудові договори для майбутньої служби у хорватській поліції39.

Сербська сторона обурювалася такими реформами Перехідної поліції. У своїх заявах серби наголошували на необхідності адекватного та своєчасного вирішення соціальних питань тих працівників ППС, що припинять роботу в поліції. Також висувалася вимога звести до мінімуму направлення співробітників Перехідної поліції до інших відділків поза місцем проживання працівників.

За посередництва УНТАЕС було скасовано тримісячний випробувальний термін, щоб мінімізувати суб'єктивність оцінки роботи окремих поліціянтів. Також було скасовано вимогу здавати професійні іспити, за винятком тих працівників, які не мали достатньої кваліфікації40.

\footnotetext{
35 Šeks V. Mirna reintegracija Hrvatskoga Podunavlja i izbori za tijela lokalne samouprave // Mirna reintegracija Hrvatskoga Podunavlja: znanstveni, empirijski i iskustveni uvidi. [Uredili Dražen Živić i Sandra Cvikić]. Zagreb - Vukovar, Institut društvenih znanosti Ivo Pilar - Područni centar Vukovar, 2010. S. 3844; UNTAES razočaran hrvatskom vladom // Vukovarske novine. Br. 92 (26 april 1997). S. 3; Danju i noću 720 vojnika UN čuvaće gradove i sela // Vukovarske novine. Br. 96 (26 juli 1997). S. 5; Obrenović M. Eksplozija na groblju u Vukovaru // Vukovarske novine. Br. 84 (9 novembar 1996). S. 6; Specijalci UNTAES-a upotrebili suzavac // Vukovarske novine. Br. 87 (10 januar 1997). S. 2; Članovi zvanične srpske delegacije fizički napadnuti // Vukovarske novine. Br. 93 (17 maj 1997). S. 2.

36 Barić N. Op. cit. (drugi dio). S. 330-332. Srbi strahuju za svoj opstanak // Vukovarske novine. Br. 88 (1 februar 1997). S. 3.

37 Problemi u Prelaznim policijskim snagama // Vukovarske novine. Br. 95 (5 juli 1997). S. 3.

${ }^{38}$ Holjevac Tuković A. Op. cit. S. 109.

39 Vučković G. Nepristrasnost i profesionalnost // Vukovarske novine. Br. 95 (5 juli 1997). S. 3.

40 Problemi u Prelaznim policijskim snagama... S. 3.
} 
Після регіональних виборів у Подунав'ї навесні 1997 р. хорватська влада на вимогу УНТАЕС почала працювати над тим, аби національний склад поліції у регіоні відповідав перепису 1991 р. Згідно з доповіддю уряду Хорватії від 22 вересня 1997 р., цього вдалося досягти стосовно начальників та їхніх заступників на 15-ти поліційних пунктах і двох поліційних дільницях Подунав'я41.

Керівництво ППС у жовтні 1997 р. заявило про успішність діяльності правоохоронних органів регіону, зазначивши, що у районі хорватського Подунав'я були припинені два великі потоки контрабанди сигарет та автомобілів ${ }^{42}$. Задля збільшення безпеки громадян у роботі Перехідної поліції було введено телефонну «гарячу лінію», куди можна було б подати будь-які скарги на роботу співробітників поліції. Заявники мали право отримати результати розслідування від відповідних працівників цивільного підрозділу УНТАЕС43.

У листопаді 1997 р. депутати Віча общин звернулися до громадян підтримати сербських членів ППС, котрі відповідно до рішення нового (з вересня 1997 р.) глави УНТАЕС Вільяма Волкера повинні були вдягнути хорватську поліційну форму та поступово (упродовж грудня) ставати частиною хорватської поліції44.

15 грудня 1997 р. В. Волкер у штабі УНТАЕС у Вуковарі передав міністру МВС Хорватії Івану Пенічу командування над ППС. Безпосереднє управління Перехідною поліцією поклали на заступника міністра МВС Йошко Морича. На той час вона складала 1715 осіб (829 хорватів, 834 сербів і 52 представники інших національних меншин) ${ }^{45}$. Керівник Перехідної адміністрації до завершення терміну дії мандату УНТАЕС (тобто, до 15 січня 1998 р.) зберігав свої повноваження з можливістю втручатися у разі необхідності, якщо діяльність ППС суперечитиме Ердутській угоді або резолюціям РБ ООН. Було наголошено на необхідності збереження збалансованого співвідношення хорватських і сербських працівників, а також представництва інших національних меншин. Цивільна поліція УНТАЕС (400 членів) залишилася до кінця мандату Перехідної адміністрації 46.

На прес-конференції, присвяченій передачі ППС до складу хорватської поліції, I. Пеніч заявив, що впродовж 1997 р. Хорватія приділяла велику увагу підготовці працівників ППС, серед яких було багато тих, хто взагалі не закінчив школу поліції. Для них, незалежно від їх національної належності, було організовано підготовчі курси в Академії поліції у Загребі, а в Істрії пройшла підготовка для членів спеціальних підрозділів ${ }^{47}$.

Офіційно ППС влилися у хорватську поліцію 16 січня 1998 р. - після завершення мандату УНТАЕС у Подунав"ї48.

Включення Перехідної поліції до складу Міністерства внутрішніх справ Республіки Хорватія завершило процес реформування поліцейських сил у хорватському Подунав'ї. Були задоволені численні вимоги щодо національного складу працівників поліції, що було гарантією безпеки всіх громадян цієї місцевості. На прохання уряду

\footnotetext{
41 Holjevac Tuković A. Op. cit. S. 109.

42 Stanje sigurnosti // Glas Slavonije. 1997. 27.10. S. 4.

43 «Halo, je l' to 'vruća' linija» // Glas Slavonije. 1997. 10.10. S. 12; Holjevac Tuković A. Op. cit. S. 109.

44 Obrenovic M. Veliki problemi i niz nerešenih pitanja // Vukovarske novine. 1997. 5.12. S. 2.

45 Olujni mir: kronologija hrvatske misije mira na Dunavu. [ured. V. Škare-Ožbolt, I. Vrkić]. Zagreb: Narodne novine, 1998. S. 326.

46 Holjevac Tuković A. Op. cit. S. 109.

47 Pandža L. Prijelazna policija pod nadzorom MUP-a // Vjesnik (Zagreb). 1997. 16 prosinca. S. 1-2.

48 Barić N. Op. cit. (drugi dio). S. 329-330.
} 
Хорватії, задля забезпечення додаткової безпеки для мешканців регіону цивільна поліція ООН залишилася ще на дев'ять місяців після відходу УНТАЕС, що було підтверджено Радою Безпеки у Резолюції № $1145^{49}$.

Загалом поза полем зору даної розвідки залишаються питання наявності (чи відсутності) міжетнічних конфліктів у лавах ППС і деякі інші аспекти діяльності Перехідної поліції. Сподіваємося, вони стануть предметом подальших досліджень цієї проблематики.

Таким чином, упродовж реінтеграції Східної Славонії до державно-правового поля Хорватії у другій половині 1990-х років важливим елементом цього процесу стало створення та функціонування Перехідних сил поліції. Задумані як тимчасовий міжнаціональний (переважно хорватсько-сербський) збройний допоміжний контингент, вони діяли у період 1996-1997 рр. Різне бачення сторонами конфлікту ролі та місця ППС утруднювало їхнє створення та функціонування. Головними проблемами Перехідної поліції були знаходження оптимального балансу національного співвідношення у підрозділі, боязнь сербів втратити роботу після ліквідації ППС. Почавши свою роботу як переважно сербська міліарна одиниця, з плином реінтеграції Перехідна поліція поступово «хорватизувалася» і наприкінці 1997 р. була передана керівництвом УНТАЕС у підпорядкування МВС Хорватії.

Зрозуміло, що повністю проводити паралелі між хорватськими й українськими прикладами неможливо - зважаючи на обставини, умови, геополітичних гравців і т.д. Однак досвід Хорватії, зокрема в організації перехідної поліції, можна використати, аби по можливості уникнути помилок і мінімізувати труднощі, з якими зіштовхнеться Україна під час ймовірної реінтеграції своїх східних територій.

\section{REFERENCES}

Baric, N. (2011). Srpska oblast Istočna Slavonija, Baranja i Zapadni Srijem - od «Oluje» do dovršetka mirne reintegracije hrvatskog Podunavlja (prvi dio) [The Serb district of Eastern Slavonia, Baranja and Western Syrmia - from the Croatian operation «Storm» to the completion of the peaceful reintegration of the Croatian Danube region (Part one)]. Scrinia Slavonica: Godišnjak Podružnice za povijest Slavonije, Srijema i Baranje Hrvatskog instituta za povijest, 11 (1), 393-454 [in Croatian].

Baric, N. (2012). Srpska oblast Istočna Slavonija, Baranja i Zapadni Srijem - od «Oluje» do dovršetka mirne reintegracije hrvatskog Podunavlja (drugi dio) [The Serb district of Eastern Slavonia, Baranja and Western Syrmia - from the Croatian operation «Storm» to the completion of the peaceful reintegration of the Croatian Danube region (Part two)]. Scrinia Slavonica: Godišnjak Podružnice za povijest Slavonije, Srijema i Baranje Hrvatskog instituta za povijest, 12 (1), 323-370 [in Croatian].

Bilandzic, D. (1999). Hrvatska moderna povijest [Croatian current history]. Zagreb: Golden Marketing [in Croatian].

Coleiro, C. (2002). Bringing Peace to the Land of Scorpions and Jumping Snakes: Legacy of the United Nations in Eastern Slavonia and Transitional Missions. Canadian Peacekeeping Press.

Holjevac Tukovic, A. (2015). Proces mirne reintegraciji Hrvatskog Podunavlja [The process of peaceful reintegration of the Croatian Danube region]. Zagreb: Despot infinitus [in Croatian].

Klein, J.P. (2010). UNTAES - sazeto izvjesce misije [UNTAES - summary mission report]. In: D. Živić, S. Cvikić (Eds). Mirna reintegracija Hrvatskoga Podunavlja - znanstveni, empirijski i iskustveni uvidi. Zagreb-Vukovar: Institut društvenih znanosti Ivo Pilar, 17-22 [in Croatian].

Klemenncic, M. \& Schofield, C. (1996). Croatia's territorial consolidation and prospects for the future. GeoJournal, 38 (4), 393-398.

Lukic, R. (1994). Greater Serbia: A New Reality in the Balkans. Nationalities Papers, 22 (1), 49-70.

Nahirnyi, M. (2007). Stanovlennia ta rozvytok Respubliky Khorvatiia: derzhavno-politychnyi aspect [The creation and development of the Republic of Croatia]. Novovolynsk: Minotavr [in Ukrainian].

Pavlicevic, D. (2000). Povijest Hrvatske [History of Croatia]. Zagreb: Naklada P.I.P. Pavicic [in Croatian].

${ }^{49}$ Holjevac Tuković A. Op. cit. S. 109. 
Seks, V. (2010). Mirna reintegracija Hrvatskoga Podunavlja i izbori za tijela lokalne samouprave [Peaceful reintegration of the Croatian Danube region and elections for local self-government bodies]. In: D.Živić, S. Cvikić (Eds). Mirna reintegracija Hrvatskoga Podunavlja - znanstveni, empirijski i iskustveni uvidi. Zagreb-Vukovar: Institut društvenih znanosti Ivo Pilar, 38-44 [in Croatian].

Škare-Ožbolt, V. \& Vrkić, I. (Ed.). (1998). Olujni mir: kronologija hrvatske misije mira na Dunavu. Zagreb: Narodne novine [in Croatian].

Tatalovic, S. (1997). Manjinski narodi i manjine [Minority peoples and minorities]. Zagreb: IP Prosvjeta; SKD Prosvjeta [in Croatian].

\section{Mykola Nahirnyi}

(Volodymyr-Volyn Pedagogical College named after A.Yu. Krymskyi, Volodymyr-Volyn, Ukraine) ORCID: http://orcid.org/0000-0002-9319-8540

\section{Transitional Police Forces During the Reintegration of the Croatian Podunavlje Region: Lessons for Ukraine}

The peculiarities of creation and activity of the Transitional Police Forces in the territory of the Croatian Podunavlje region during the reintegration of this region to the state legal framework of the Republic of Croatia are disclosed in the paper.

At the beginning of 1996, the UN Security Council adopted resolution № 1037 on establishing the United Nations Transitional Authority for Eastern Slavonia (UNTAES). It had the tasks of reintegration of the territory into the structure of Croatia. The components of reintegration were demilitarization of the region, administrative reintegration, social reintegration, holding local elections, recovery of economic activity. The organization of the Transitional Police Force (TPF) work became one of the elements of gradual reintegration.

The work of the TPF was preceded by the combined training of the Croatian and Serbian law enforcers abroad and after that they were sent to certain sections of the demarcation line in the Podunavlje region.

A different vision of the role and place of the TPF by the parties of the conflict complicated its creation and functioning. The main problems of the TPF were searching for an optimal balance of the national proportion in the division, and the Serbians fear of losing the job after elimination of the TPF.

With the continuation of reintegration, the proportion of Croats in the TPF increased. Restructuring of the body and gradual transfer of its officers to the structure of the Croatian Ministry of Internal Affairs began from the middle of 1997.

At the end of 1997, the headquarters of the UNTAES relinquished command over the TPF to the Ministry of Internal Affairs of Croatia. Officially the TPF joined the Croatian police on January 16, 1998, after the end of the credentials of the UNTAES in Podunavlje region.

Inclusion of the TPF in the structure of the Ministry of Internal Affairs of the Republic of Croatia completed the process of police forces reforming in the Croatian Podunavlje region. Croatia's experience in the establishing of the TPF could be used to resolve the situation in Donbas.

However, it is inexpediently to draw complete parallels between the Croatian and Ukrainian examples.

Keywords: UNTAES, reintegration, TPF, Podunavlje region 